\title{
Red drum Sciaenops ocellatus mortalities associated with Streptococcus iniae infection
}

\author{
A. Eldar ${ }^{1}$, S. Perl ${ }^{2}$, P. F. Frelier ${ }^{3}$, H. Bercovier ${ }^{4, *}$ \\ 'Department of Poultry and Fish Diseases, The Kimron Veterinary Institute, POB 12, Bet Dagan 50250, Israel \\ ${ }^{2}$ Department of Pathology. The Kimron Veterinary Institute, POB 12, Bet Dagan 50250, Israel \\ ${ }^{3}$ The Department of Veterinary Pathobiology, Texas A\&M University, College Station, Texas 77843-4467, USA \\ ${ }^{4}$ Department of Clinical Microbiology, The Hebrew University-Hadassah Medical School, POB 12272 Jerusalem, 91010 Israel
}

\begin{abstract}
We isolated for the first time Streptococcus iniae strains associated with diseased marine fish. Diseased red drum Sciaenops ocellatus were lethargic, and presented external signs fexophthalmia and loss of orientation) resembing those of freshwater fish infected by S. iniae. Skin lesions, extending to a necrotizing myositis, were typical of $S$. iniae infection of red drum. Histopathological findings indicate that $S$. iniae infection in red drum produces a chronic disease with systemic involvement characterized by multiple necrotic foci. Molecular epidemiology (RFLP [restriction fragment length polymorphism] ribotyping) revealed that 2 different ribotypes were involved in a single outbreak. The first is the ECORI 'Israeli' trout and tilapine ribotype (Hind III type a strains), while the second is the ECoRI 'American' ribotype (Hind III type b strains), typical of tilapines farmed in Texas and Idaho.
\end{abstract}

KEY WORDS: Red drum $\cdot$ Streptococcus iniae $\cdot$ Pathology $\cdot$ DNA $\cdot$ Ribotyping

\section{INTRODUCTION}

Streptococcus iniae was first described in 1976 , when isolated from purulent skin lesions of a freshwater Amazonian dolphin Iniae geoffrensis (Pier \& Madin 1976). Subsequently, the same bacterium was associated with outbreaks of fish disease in Israel (Eldar et al. 1995a) and in North America (Perrera et al. 1995, Eldar et al. 1995b). S. iniae was cultured from diseased rainbow trout Oncorhynchus mykiss and tilapines (Oreochromis aurea $\times$ Oreochromis nilotica hybrids), and the disease has been reproduced by intraperitoneal injection of the bacterium (Eldar et al. 1995a). In these species, experimental and natural infection produces panophthalmitis and meningitis, with only minor pathological changes in other organs (Eldar et al. 1995a). Israeli and American S. iniae isolates are biochemically and serologically identical (Eldar et al. 1997), and their genomic relatedness (accepted as the major criterion to delineate geno-

-Addressee for correspondence.E-mail: hb@cc.huji.ac.il species [Wayne et al. 1987, Grimont 1988, Stackenbrandt \& Teuber 1988]) places them in the same genetic group as the ATCC 29178 type strain. RFLP ribotyping (Grimont \& Grimont 1986) with a DNA probe ( $E$. Coli rRNA gene) comprising genes with evolutionary highly conserved sequences (Brosius et al. 1981 ) is the only tool presently available for the differentiation of $S$. iniae clinical isolates (Eldar et al. 1997). Hybridization of $E$. coli rRNA probes to digests of chromosomal DNA identifies several fragments containing rDNA coding sequences: the length distribution of such fragments varies within the isolates, providing a useful restriction fragment length polymorphism (RFLP) for strain differentiation (Stull et al. 1988). RFLP ribotyping of $S$. iniae isolates has shown that American strains isolated from tilapia cluster in a single ribotype, whereas Israeli strains isolated from tilapia and trout belong to another epidemiological clone (Eldar et al. 1997).

In the summer of 1996 , mortalities peaking at $2 \%$ daily were recorded among cage cultured red drum Sciaenops ocellatus at the Israeli Mediterranean coast. Clinical signs included lethargy and, to a minor extent, 
protrusion of the eye together with clouding of the cornea. Erosion of the skin was noticed among nearly all diseased fish. Bacteriological culture from diseased fish gave rise to pure colonies of Gram-positive cocci. Since Streptococcosis of fish is caused by various genera of Gram-positive cocci (Wallbanks et al. 1990, Williams et al. 1990, Kusuda et al. 1991, Nieto et al. 1995, Perrera et al. 1995, Domenech et al. 1996, Eldar et al. 1996), specific diagnosis combined with pathological studies were necessary in order to interpret the phenomena.

It was found that Streptococcus iniae infected red drum suffered from a long-running systemic disease accompanied by necrotizing dermatitis. The bacterial isolates involved in this infection were subjected to epidemiological analysis (RFLP ribotyping), demonstrating the involvement of 2 epidemiological clones in a single outbreak.

\section{MATERIALS AND METHODS}

Sampling procedure for histopathology. Samples from 10 diseased fish, including eye, brain, heart, spleen, kidney, livers, muscle and intestine were fixed in $10 \%$ neutral buffered formalin solution. Sections were stained by Haematoxylin-Eosin and Giemsa. Bacteria were identified by MacCallum-Goodpasture stain. Gross lesions were also recorded.

Isolation and phenotypic characterization of bacteria from diseased fish. Samples from kidneys and brains were collected from 8 diseased fish (KFP 55-63) and streaked on Columbia agar base (Difco) supplemented with $5 \%$ (vol./vol.) defibrinated sheep blood. Skin samples (KFP 64,65) were isolated on the same media as above, but supplemented with $0.04 \%$ ( $\mathrm{wt} / \mathrm{vol}$.) of sodium azide (Sigma). In parallel, skin samples were also inoculated on normal blood agar plates and on MacConkey agar (Difco). Plates were incubated at $24^{\circ} \mathrm{C}$ for 24 to $48 \mathrm{~h}$. Biochemical reactions were performed on API 20 STREP and API $50 \mathrm{CH}$ systems (Bio Merieux, France) according to the manufacturer's instructions, except the temperature which was adjusted to $24^{\circ} \mathrm{C}$. Results were read after incubation of $24 \mathrm{~h}$

DNA-DNA hybridizations. Five randomly selected isolates (KFP 56, 58, 60, 62 and 65) were incubated with lysozyme and mutanolysin and their DNAs were extracted with phenol-chloroform as described previously (Eldar et al. 1995b). DNA-DNA hybridizations were performed by the hydroxyapatite (Bio Rad, Hercules, CA) method (Brenner et al. 1969) with modifications regarding the volumes employed: $15 \mu \mathrm{g}$ of sheared DNA (500 to $600 \mathrm{bp}$ ) were hybridized with $5 \mathrm{ng}$ of nick-translated (Amersham, Buckinghamshire,
UK) ${ }^{32}$ P labeled DNA (30 000 to $50000 \mathrm{cpm}$ ) of Streptococcus iniae ATCC 29178 , in a final volume of $100 \mu \mathrm{I}$ The reassociation of the single-stranded DNAs was allowed to proceed in $280 \mathrm{mM}$ PBS, for $18 \mathrm{~h}$ at $62^{\circ} \mathrm{C}$. Reactions were done in duplicate, and each run was performed twice. The levels of DNA relatedness (relative binding ratio or RBR) were calculated as published before (Eldar et al. 1995b). The rate of reassociation of the labeled DNA was routinely 5 to $6 \%$, which was subtracted from the absolute ratios of the hybridizations.

Ribotyping. Four $\mu \mathrm{g}$ of genomic DNAs prepared from isolates KFP 56, 58, 60, 62 and 65 were completely digested $\left(16 \mathrm{~h}\right.$ at $37^{\circ} \mathrm{C}$; under the conditions specified by the manufacturer) with $50 \mathrm{U}$ each of Hind III and EcoRI restriction enzymes (Promega, Madison, WI), separated by electrophoresis on a $20 \mathrm{~cm}$ long $1 \%$ agarose gel (at $55 \mathrm{~V}$ for $17 \mathrm{~h}$ in $49 \mathrm{mM}$ tris-acetate-2mM EDTA), and blotted by capillary transfer (Southern 1975) onto positively charged nylon membranes (Boehringer, Mannheim, Germany). The membranes were then removed and the DNA was fixed by UV crosslinking. Prehybridization and hybridization ( 3 and $20 \mathrm{~h}$, respectively) were carried out in $50 \mathrm{mM}$ tris- $\mathrm{HCl}$ ( $\mathrm{pH} 7.5), 1 \mathrm{M} \mathrm{NaCl}, 1 \%$ sodium dodecyl sulfate (SDS), $10 \%$ dextran sulfate, $0.1 \%$ blocking reagent. The DNA probe, a $7.5 \mathrm{~kb} B a m H I$ fragment of $\mathrm{pKK}_{3535}$ comprising the E. coli rRNA B operon (Brosius et al. 1981) was labeled by random oligopriming, using a mixture of hexanucleotides and reverse transcriptase in the presence of $0.35 \mathrm{mM}$ digoxenin-11-dUTP (Boehringer).

After hybridization, filters were washed twice with $0.15 \mathrm{M}$ sodium citrate solution, containing $0.1 \%$ SDS for $15 \mathrm{~min}$ at room temperature. Chemiluminescence detection procedures were done, as recommended by the manufacturer (Boehringer), by incubating the membranes in the presence of an anti-digoxigenin antibody linked to alkaline phosphatase (Boehringer), and the alkaline phosphatase substrate AMPPD 3(2'-spiroadamantane)-4-methoxy-4-(3"-phosphoryloxy)phenyl-1,2-dioxetane (Boehringer). Filters were autoradiographed by exposure to X-Omat AR 5 films (Kodak, Rochester, NY) from 10 to $120 \mathrm{~min}$ at room temperature.

\section{RESULTS}

\section{Clinical signs and histopathology}

All diseased fish were lethargic and refused feeding Out of the 10 diseased fish, 7 presented skin lesions and $4 \mathrm{fish}$ had ocular changes. None of them had signs of petecchia or haemorrhage, and no remarkable changes were noticed on the gills of the diseased fish. 
Fig. 1. Brain. Acute meningitis. Fibrinopurulent exudate covering the meningeal layers. HaemotoxylinEosin $\times 200$

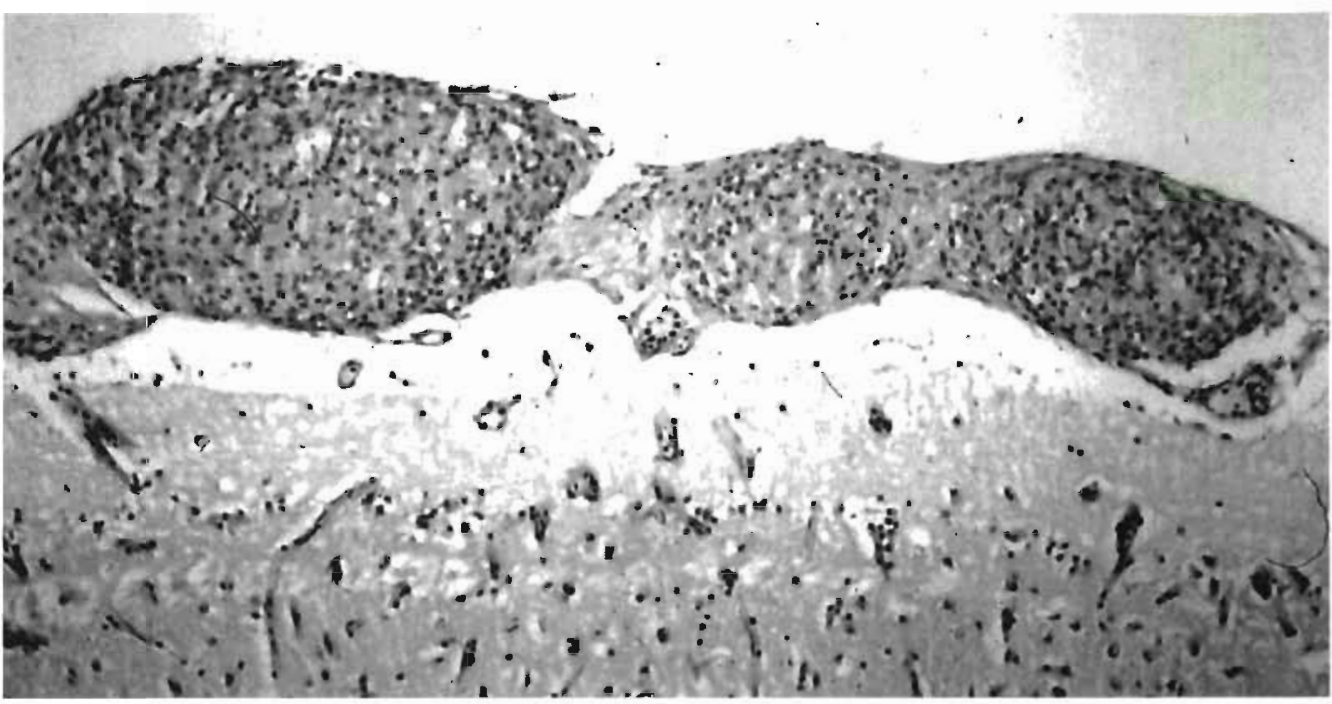

The liver was of normal appearance and size, and the heart was not enlarged, but the epicardium of all the fish was roughened and opaque. The spleen and kidney were congested in all the fish examined. When the brain was dissected, the meningi were congested and covered by a muco-purulent exudate.

Histopathological examination of the diseased fish revealed acute to subacute meningitis consistent with the fibrino-purulent exudate covering the thickened meningeal layers which were diffusely infiltrated by heterophils and histiocytes (Fig. 1). High power magnification revealed a large number of Gram-positive cocci, partly engulfed within the cytoplasm of macrophages. Some of the brain blood vessels were filled with inflammatory cells. Multifocal infiltration of heterophils and mononuclear cells with a discrete degree of vacuolization was observed.

The epicardium was thickened and diffusely infiltrated by a large number of heterophils and histiocytes. In some sections, the pericarditis extended to the myocardium producing focal necrotic myocarditis and vascular thrombi (Fig. 2).

The normal architecture of the spleen was destroyed and replaced by multifocal to diffuse necrotic areas,
Fig. 2. Heart. Pericarditis extending to the myocardium. Vascular thrombi within the cardial blood vessels. HaemotoxylinEosin $\times 100$

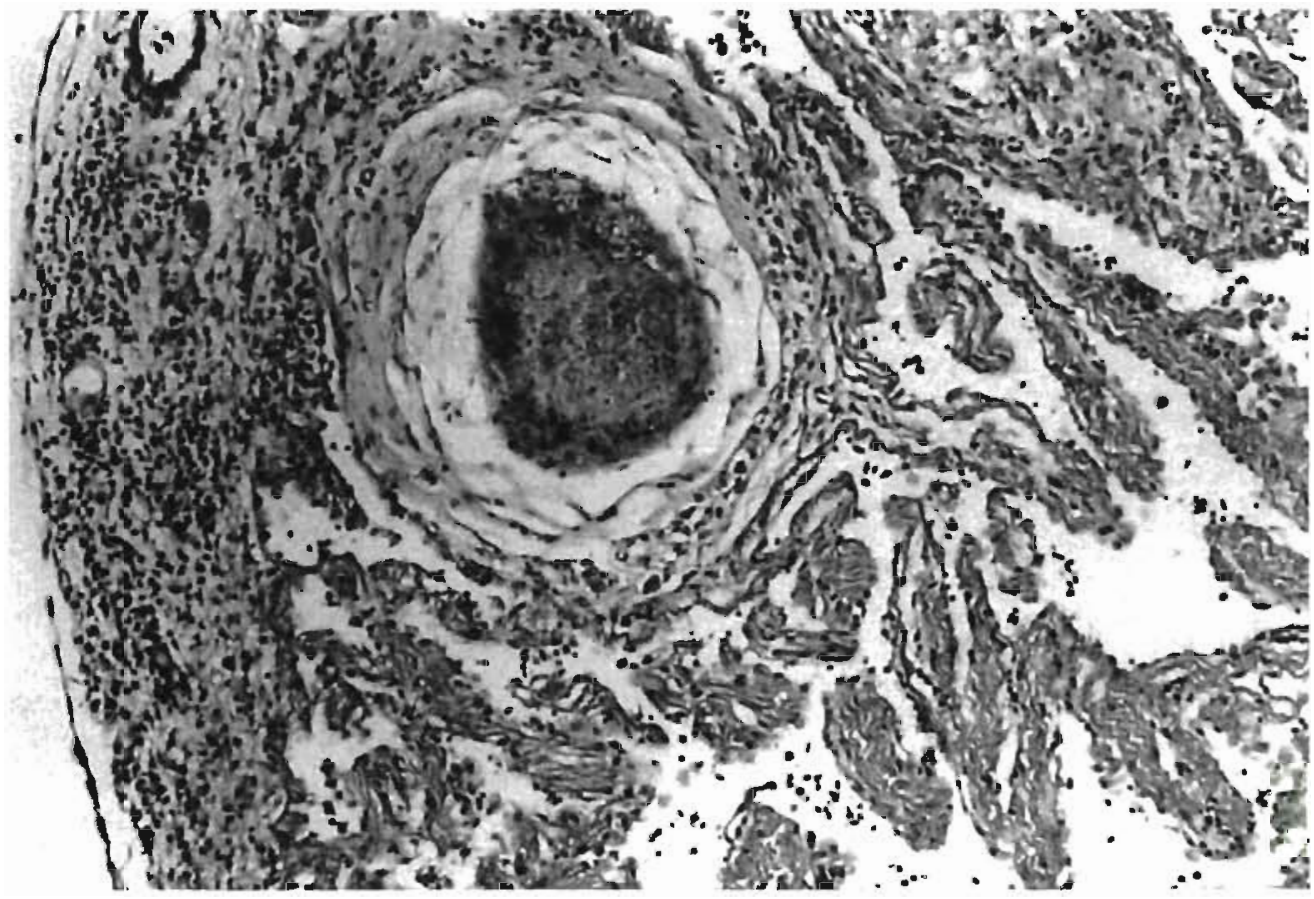




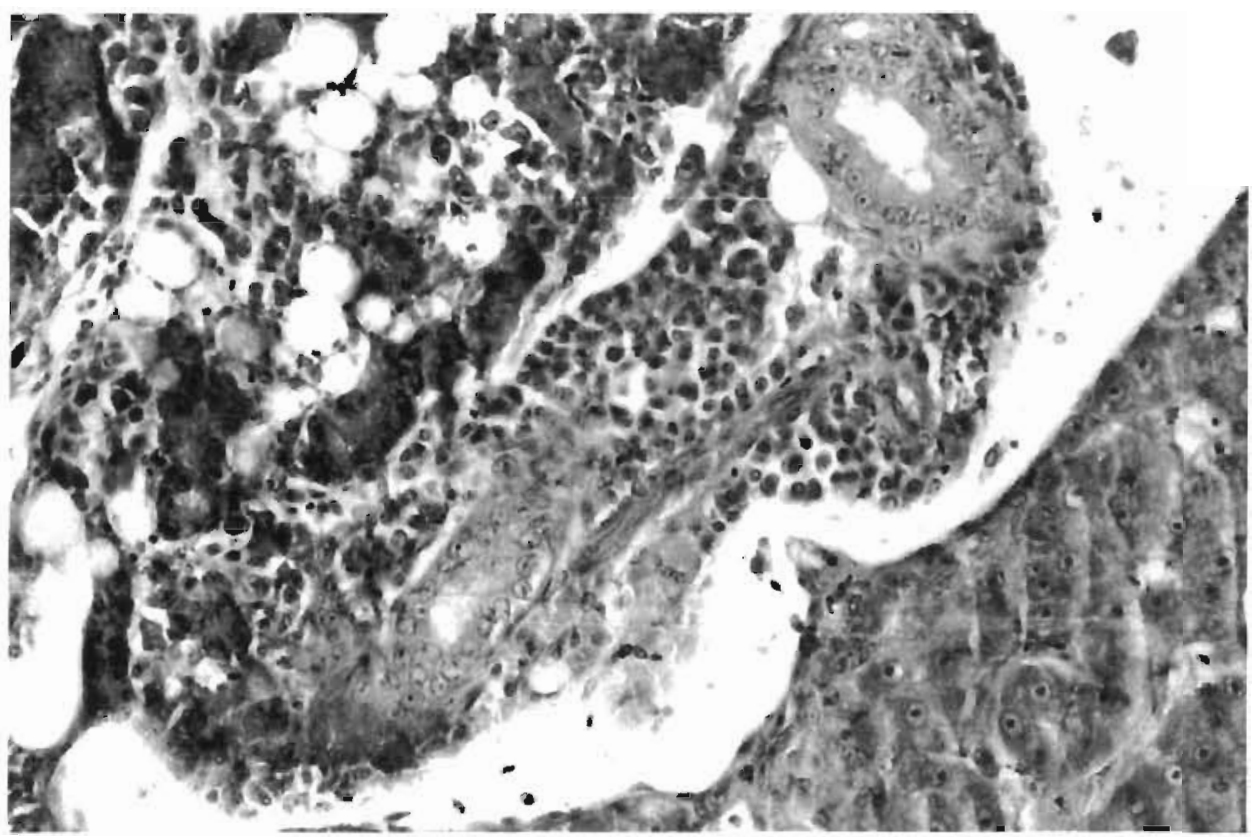

Fig. 3. Pancreas. Multifocal infiltration, mainly of mononuclear cells in proximity of the pancreatic ducts. Haemotoxylin-Eosin $\times 400$

filled with red blood cells. A large number of Grampositive cocci could be identified within the damaged areas. Similar findings were observed in the kidney.

The normal architecture of the portal spaces, bile ducts, and of the blood vessels was conserved. In the pancreatic islands, a multifocal infiltration, mainly of mononuclear cells, was apparent in proximity of the pancreatic ducts (Fig. 3)

In the skin, foci of extensive necrosis of the epidermal layer were infiltrating into the underlying subcuta- neous tissue, and adjacent muscle fibers were undergoing coagulative necrosis (Figs, 4 \& 5). Gram-positive cocci were visualized in the skin and muscle sections.

\section{Isolation and characterization of bacteria}

All brain and kidney cultures yielded pure colonies of $\beta$-haemolytic Gram-positive cocci. Mixed cultures of Gram-positive cocci and Gram-negative rods were

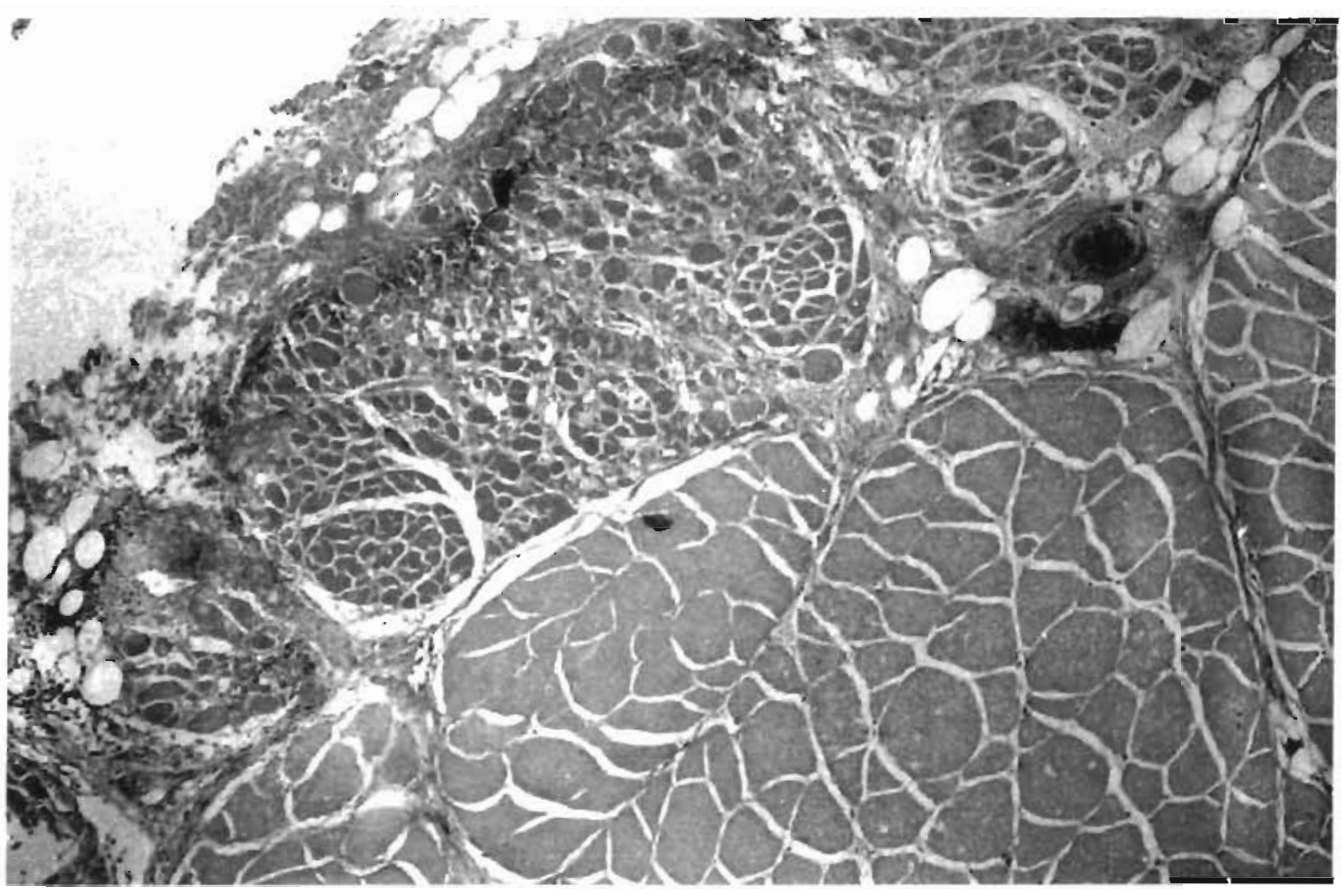

Fig. 4. Skin. Epidermal erosion, progressing to the underlying connective and muscular tissues. HaemotoxylinEosin $\times 100$ 
Fig. 5. Muscle. Areas of coagulative necrosis. HaemotoxylinEosin $\times 400$

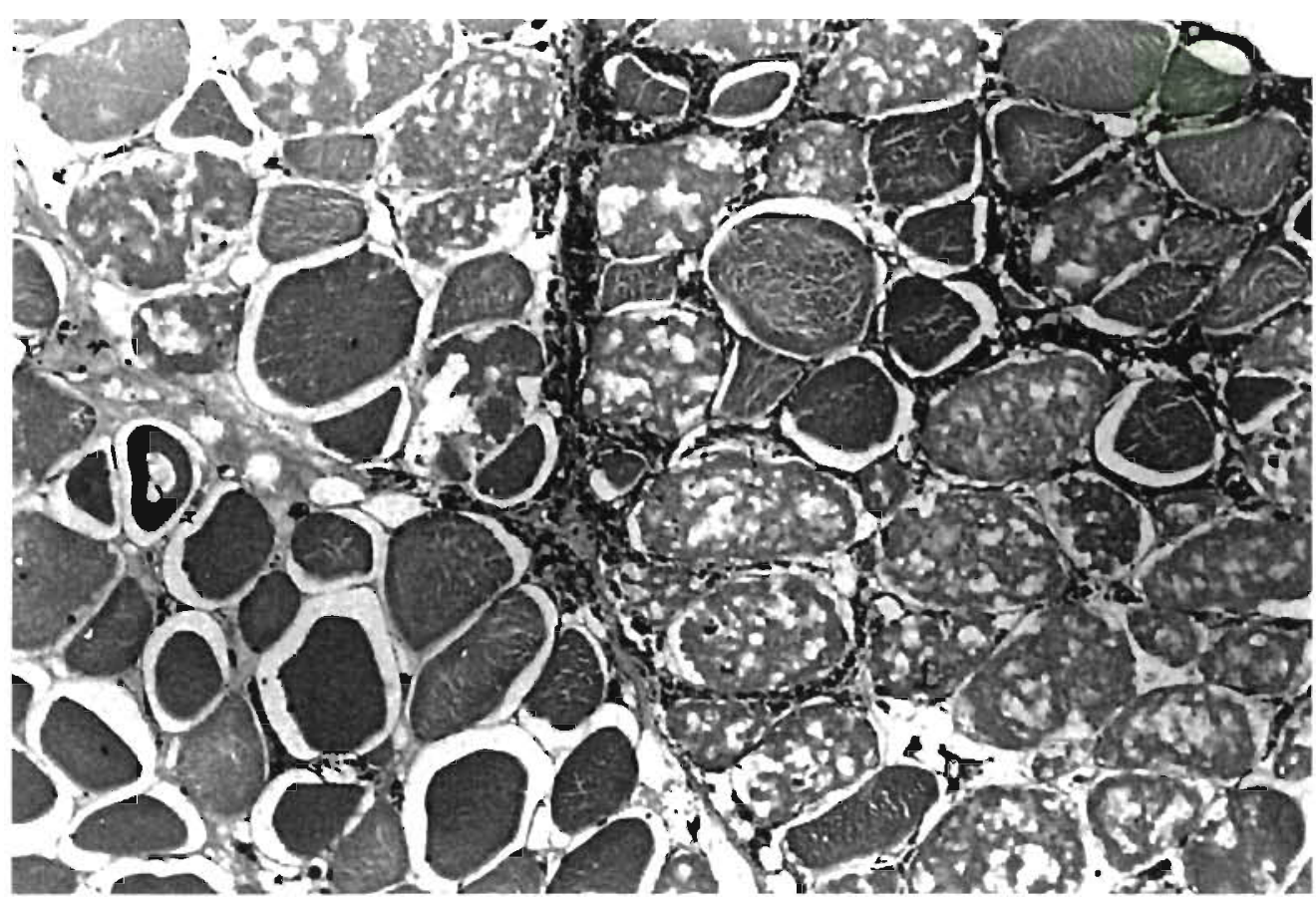

obtained from the skin. When skin samples were cultured on blood agar supplemented with sodium azide $(0.04 \%)$, a large number of $\beta$-haemolytic Gram-positive cocci were recognized. Skin isolates other than Gram-positive cocci were considered to be contaminants for the following reasons: (1) on sodium azide blood agar, Streptococcus iniae isolates were predominant, (2) histopathological findings revealed dermatitis and myositis with microcolonies of Gram-positive cocci within the muscles and the epidermis.

The biochemical profile of all isolates, determined by the API 20 STREP kit was identical to that of the Streptococcus iniae trout and tilapine isolates previously described (Eldar et al. 1995b). VP, HIP, $\alpha$ and $\beta$-GAL were negative, while ESC, PYRA, PAL, LAP and ADH were positive. Ribose, mannitol, trehalose, starch and glycogen were fermented, while arabinose, sorbitol, lactose, inuline or raffinose were not utilized. The metabolic pattern obtained with the API $50 \mathrm{CH}$ kits was also identical to that of trout and tilapine isolates (acidification of ribose, galactose, D-glucose, D-fructose, D-mannose, mannitol, M-D mannoside, arbutine, esculine, salicine, cellobiose, maltose, saccharose, trehalose, melezitose starch, glycogen and $\beta$-gentobiose).

The identification of the red drum isolates as Streptococcus iniae was further confirmed by DNA-DNA hybridization tests. When hybridized to $S$. iniae ATCC 29178 type strain, all 5 red drum isolates, including the skin isolate, exhibited levels of DNA relatedness (RBR) of 84 to $89 \%$. Hence, they should be classified (Wayne et al. 1987, Grimont 1988) as S. iniae strains.

\section{RFLP ribotyping}

The 5 isolates examined fell into 2 different ribotypes (Fig. 6a). One isolate, collected from the kidney, revealed 6 restriction fragments, including the unique $\sim 6,0 \mathrm{~kb}$ band typical of the Israeli ECoRI strains (Eldar et al. 1997). The other 4 isolates, including the skin isolate, presented 5 restriction fragments, identical in size

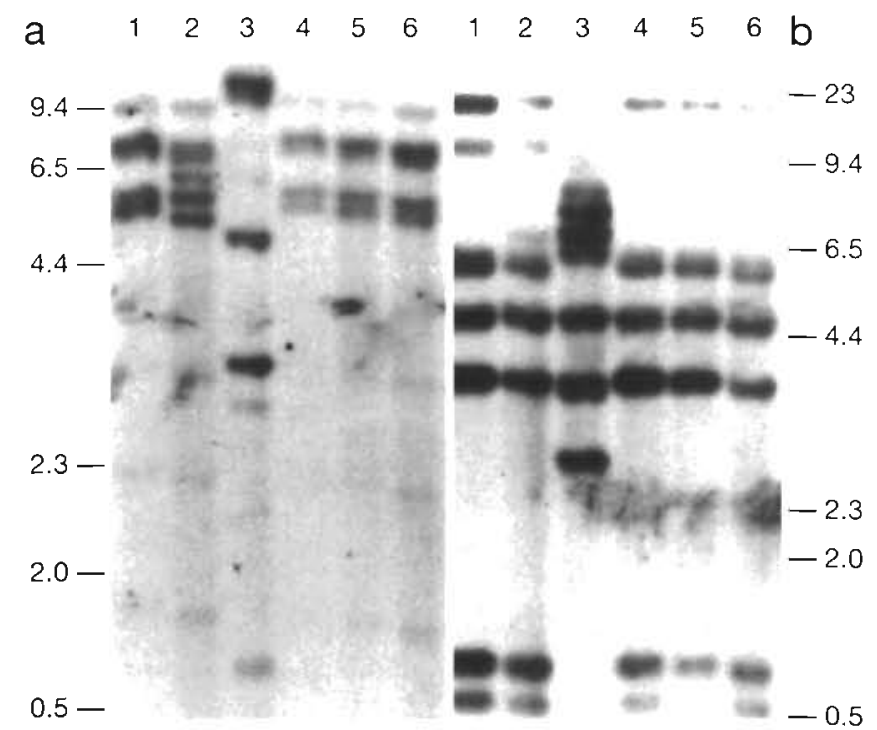

Fig. 6. (a) ECoRI and (b) Hind III ribotyping of red drum isolates. Lane 1: KFP 56; lane 2: KFP 58; lane 3: control (unrelated Streptococcus sp. isolated from rainbow trout in Italy); lane 4: KFP 60; lane 5: KFP 62; lane 6: KFP 65 
to the strains isolated from American tilapia (Eldar et al. 1997).

Ribotyping after cleavage with Hind III digests (Fig. 6b) sustained the existence of 2 epidemiological clones. The Hind III ribotype a isolates matched the cluster of American EcoRI tilapine isolates, whereas the Hind III ribotype b isolate was found to be identical to the Israeli trout strains (Eldar et al. 1997).

\section{DISCUSSION}

Although infections of marine fish species due to Gram-positive cocci have been described (Kitao 1993), most of the strains involved were poorly characterized, and no definitive conclusions as to the taxonomic status of the aetiologic agents were made. Lactococcus garvieae (Collins et al. 1984) (junior synonym: Enterococcus seriolicida (Domenech et al. 1993, Eldar et al. 1996]) and Streptococcus parauberis (Domenech et al. 1996) are the exceptions. L. garvieae was associated with disease outbreaks in the Japanese yellowtail Seriola quinqeradiata (Kusuda et al. 1991), whereas $S$. parauberis was isolated from diseased turbot (Scophthalmus maximus) in Spain (Domenech et al. 1996).

Streptococcus iniae (Pier \& Madin 1976) has been previously associated with diseases of 2 freshwater fish species, namely tilapines (Oreochromis spp.) and rainbow trout Oncoryhnchus mykiss (Eldar \& Ghittino 1995, Eldar et al. 1995a, Perrera et al. 1995). The data reported in the present communication show, for the first time, that $S$. iniae may also cause a disease in marine fish species. Since the genetic data of the strains isolated from red drum (DNA relatedness to the ATCC strain of $>80 \%$ ) correlated well with their biochemical profile, their identification as $S$. iniae is assured (Wayne et al. 1987, Grimont 1988, Stackenbrandt $\&$ Teuber 1988). The range of taxons of Grampositive cocci associated with diseases of marine fish species should now include 3 species: Lactococcus garvieae, $S$. parauberis and $S$. iniae.

Due to the limited number of studies concerning infections by Gram-positive cocci in marine fish species, the value of pathology as a diagnostic tool is still limited. Infected turbot Scophthalmus maximus were reported to present general signs of an acute disease, including haemorrhage on the anal and pectoral fins, pettechiae on the abdomen, purulent ophthalmitis, mucohaemorrhagic enteritis, congestion of internal organs and hepatomegaly (Domenech et al. 1996). Lactococcus garvieae infections in Japanese yellowtail Seriola quinqeradiata are also accompanied by nonspecific lesions, such as congestion and haemorrhage of the viscera (Kusuda et al. 1991). In both cases, the lesions described suggest a septicemic disease. This is also true in the case of 'Enterococcus sp.' infection in turbot (Nieto et al. 1995). In contrast, Streptococcus iniae infections in red drum Sciaenopes ocellatus resulted in an acute to subacute disease characterized by multiple necrotic lesions of the internal organs, as well as of the skin. The lesions observed among the $S$. iniae infected red drum differed from those produced by the same agent in freshwater fish species. S. iniae infections in tilapines (Eldar et al. 1995a) and trout (Eldar \& Ghittino 1995) produce an acute disease in which the prominent lesions are meningitis (in trout) and meningoencephalitis (in tilapines). In these species, lesions other than those affecting the CNS are mild or absent. Differences of (fish) species and variations in environmental conditions might be responsible for the different pathological lesions.

The present study confirms the importance of ribotyping as an epidemiological tool, showing that, as in the case of the Israeli and American Streptococcus iniae isolates obtained from freshwater fish species (Eldar et al. 1997), infections are not necessarily sustained by a single epidemiological clone. The presence of the 'Israeli' clone is not surprising, and might be explained by contamination from food, personnel or mechanical devices. Involvement of the 'American' clone, although unexpected, might be related to the fact that the fish (red drum, as fry) were imported to Israel from the USA.

The data based on the first outbreak of Streptococcus iniae infection in red drum should be used to control future importation of fry from one country to another in order to prevent spread of the disease.

Acknowledgements. This work was supported by a joint American-Israeli grant (BARD IS-2727-96R)

\section{LITERATURE CITED}

Brenner DJ, Fanning GR, Rake AV, Johnson KE (1969) Batch procedure for thermal elution of DNA from hydroxyapatite. Anal Biochem 28:447--459

Brosius J, Ulrich A, Raker MA, Gray A, Dull TJ, Gutell RR, Noller HF (1981) Construction and fine mapping of recombinant plasmids containing the rRNA ribosomal RNA operon of E. coli. Plasmid 6:112-118

Collins MD, Farrow FAE, Phillips NA, Kandler O (1984) Streptococcus garvieae sp. nov. and Streptococcus plantarum sp. nov. J Gen Microbiol 129:3427-3431

Domenech A, Prieta J, Fernandez-Garayzabal JF, Collins MD, Jones D, Dominguez L (1993) Phenotypic and phylogenetic evidence for a close relationship between Lactococcus garvieae and Enterococcus seriolicida. Microbiologia 9:63-68

Domenech A, Fernandez-Garayzabal JF, Pascual C, Gracia JA, Cutuli MT, Moreno MA, Collins MD, Dominguez L (1996) Streptococcosis in cultured turbot, Scophthalmus maximus (L.), associated with Streptococcus parauberis. J Fish Dis 19:33-38 
Eldar A, Ghittino C (1995) Comparative pathology and experimental vaccination in diseased rainbow trout infected by $S$. iniae and L. garvieae. Eur Ass of Fish Path, 7 th Int Cong, 10-15/9/95, Palma De Mallorca, Spain, p 27 (book of abstracts)

Eldar A, Bejerano Y, Livoff A, Hurvitz A, Bercovier H (1995a) Experimental streptococcal meningo-encephalitis in cultured fish. Vet Microbiol 43:33-40

Eldar A, Frelier PF, Asanta L, Varner PW, Lawhon S, Bercovier $\mathrm{H}$ (1995b) Streptococcus shiloi, the name for an agent causing septicemic infection in fish, is a junior synonym of Streptococcus iniae. Int J Syst Bacteriol 45:840-842

Eldar A, Ghittino C, Asanta L, Bozzetta E, Goria M, Prearo M, Bercovier $H$ (1996) Enterococcus seriolicida is a junior synonym of Lactococcus garvieae, a causative agent of septicemia and meningoencephalitis in fish. Curr Microbiol 32:85-88

Eldar A, Frelier PF, Asanta L, Varner PW, Lawhon S, Bercovier $H$ (1997) DNA restriction length polymorphisms of rRNA genes (ribotyping) allows distinction between Israeli and US $S$. iniae trouts and tilapia isolates. FEMS Microbiol Lett 151:155-162

Grimont F, Grimont PAD (1986) Ribosomal nucleic acid gene restriction patterns as potential taxonomic tools. Ann Inst Pasteur Microbiol 1378:165-175

Grimont PAD (1988) Use of DNA reassociation in bacterial classification. Can J Bacteriol 34:541-546

Kitao T (1993) Streptococcal infections. In: Inglis V, Roberts RJ, Bromage NR (eds) Bacterial disease of fish. Blackwell Scientific Publications, Oxford, p 196-210

Kusuda K, Kawai K, Salati F, Banner CR, Fryer JL (1991)

Editorial responsibility: David Bruno,

Aberdeen, Scotland, UK
Enterococcus seriolicida sp. nov., a fish pathogen. Int $\mathrm{J}$ Syst Bacteriol 41:406-409

Nieto JM, Devesa S, Quiroga A, Toranzo AE (1995) Pathology of Enterococcus sp. in farmed turbot. Scophthalmus maximus L. J Fish Dis 18:21-30

Pier GB, Madin SH (1976) Streptococcus iniae sp. nov., a beta hemolytic streptococcus isolated from an Amazon freshwater dolphin, Inia geoffrensis. Int J Syst Bacteriol 26: $545-553$

Perrera RP, Johnson SK, Collins MD, Lewis DH (1995) Streptococcus iniae associated with mortality of Tilapia nilotica $\mathrm{x}$ $T$ aurea hybrids. J Aquat Anim Health 6:335-340

Stackenbrandt E, Teuber $M$ (1988) Molecular taxonomy and phylogenetic position of lactic acid bacteria. Biochemie 70: $317-324$

Stull TT, Lipuma JJ, Edlind TD (1988) A broad-spectrum probe for molecular epidemiology of bacteria: ribosomal RNA. J Infect Dis 157:280-286

Wallbanks S, Martinez-Murcia AJ, Fryer JL, Phillips BA, Collins MD (1990) 16S rRNA sequence determination for members of the genus Carnobacterium and related lactic acid bacteria and description of Vagococcus salmoninarum sp. nov. Int J Syst Bacteriol 40:224-230

Wayne LGD, Brenner J, Colwell RR, Grimont PAD, Kandler O, Krichevsky MI, Moore LH, Moore WEC, Murray RGE, Stackenbrandt E, Starr MP, Truper GH (1987) Report of the ad hoc committee on reconciliation of approaches to bacterial systematics. Int J Syst Bacteriol 37:463-464

Williams AM, Fryer JL, Collins MD (1990) Lactococcus piscium sp. nov. a new Lactococcus species from salmonid fish. FEMS Microbiol Lett 68:109-114

Submitted: May 14, 1998; Accepted: December 14, 1998 Proofs received from author(s): April 12, 1999 